\title{
Changes in distribution and decrease in numbers during migration of the bivalve Macoma balthica
}

\author{
J. G. Hiddink*, W. J. Wolff \\ University of Groningen, Department of Marine Biology, PO Box 14, 9750 AA Haren, The Netherlands
}

\begin{abstract}
The population development of the 1998 year class of the bivalve Macoma balthica was studied by repeated sampling of a tidal flat area in the eastern Dutch Wadden Sea from May 1998 to August 2000. The juveniles migrated twice, once in mid-1998 from their primary settlement locations in the low sandy intertidal to the nursery in the high intertidal (spring migration, $25 \%$ of all juvenile M. balthica relocated from low to high intertidal) and once in late 1998/early 1999 from the nursery to the low intertidal and the subtidal (winter migration, between 8 and $15 \%$ of all 0-group (less than $1 \mathrm{yr}$ old) $M$. balthica relocated from high to low intertidal). During winter, $M$. balthica migration was most intensive at the lowest temperatures. Relative to the abundance on the tidal flats, the 1+ group (older than 1 yr) $M$. balthica (i.e. from the second summer onwards) were rare in the tidal channels of the Wadden Sea and were only slightly more common in the North Sea adjacent to the tidal inlet. During both the spring and winter migration, many bivalves disappeared from the tidal flat population. This could partly be explained by normal mortality and by emigration to the subtidal channels and the North Sea. The remaining mortality was probably due to the risks inherent in migration: predation during pelagic floating or not reaching the right locations. The number of bivalves that disappeared was very high. In spring, slightly more disappeared than relocated. In winter, $>4$ times more bivalves disappeared than relocated. Migration is obviously a very dangerous activity, therefore great advantages must be associated with the nursery use that makes such migrations necessary. An analysis of literature data on the density of $M$. balthica shows that in the eastern Dutch Wadden Sea, $90 \%$ of the population lives in the intertidal, about $10 \%$ in the adjacent North Sea, and a negligible fraction in the subtidal channels of the Wadden Sea.
\end{abstract}

KEY WORDS: Macoma balthica $\cdot$ Nursery · Migration · Mortality · Wadden Sea Resale or republication not permitted without written consent of the publisher

\section{INTRODUCTION}

Many intertidal benthic species in the Wadden Sea, a shallow coastal sea in The Netherlands, Germany and Denmark, use nurseries in the high intertidal (Beukema 1993, Flach \& Beukema 1994). A nursery is an area inhabited by many juveniles but few adults of a species. This is typical, for example, for the lugworm Arenicola marina (Farke et al. 1979), the shore crab Carcinus maenas (Klein Breteler 1976, Beukema 1991), the shrimp Crangon crangon (Kuipers \& Dapper 1984) and the bivalve Macoma balthica (Beukema 1993).

\footnotetext{
*E-mail: j.g.hiddink@biol.rug.nl
}

It is assumed that these nurseries provide juveniles of these benthic species with protection against predation by marine organisms such as shrimps, crabs and small fish (Beukema 1993), that physical disturbance is less (Flach 1992) and that perhaps feeding conditions are better (Armonies \& Hellwig-Armonies 1992). However, when nurseries are spatially separated from the locations inhabited by adults, the juveniles must migrate to and from the nurseries. Many marine benthic animals (including Macoma balthica) migrate by drifting on the current while suspended in the water column (Sigurdsson et al. 1976, Forward \& Tankersley 2001). This migration to and from the nursery is a phase with potentially very large risks: the animals are easy victims for pelagic and epibenthic predators such as fishes, and also risk ending up in the wrong location. 
For benthic animals, the risks of migration have not been studied, but there are some indications that they do have costs. Migrating lugworms Arenicola marina are eaten by the pelagic fish Osmerus eperlanus, which is unable to dig out deep-living polychaetes (Kühl 1970). The tube-dwelling amphipod Corophium volutator suffers enhanced mortality from predation by shrimps when disturbance by $A$. marina and Cerastoderma edule causes it to leave the sediment (Flach \& de Bruin 1994). In Macoma balthica in the Baltic Sea, physical disturbance increased mortality due to predation by the isopod Saduria entomon, while physical disturbance alone did not have any influence on mortality (Bonsdorff et al. 1995). Thus, leaving their burrow in the presence of predators may be dangerous for bivalves, polychaetes and crustaceans.

There are no studies on the fate of benthic animals that migrate from a suitable habitat. The fact that there is a large variation in growth and mortality rates between locations for many benthic species may be an indication that many individuals fail to migrate to the optimal location (Beukema 1993).

Macoma balthica is one of the most common and widespread bivalves in the Wadden Sea. Its early life history includes 2 migrations. M. balthica spawns in late March and April (Honkoop \& van der Meer 1997). The eggs and larvae are pelagic for a short period; in the Wadden Sea larvae settle mainly on the low tidal flats at a length of 190 to $300 \mu \mathrm{m}$ (Günther 1991, Armonies \& Hellwig-Armonies 1992). This settlement on low tidal flats is probably dictated by hydrography (Armonies \& Hellwig-Armonies 1992). In May the postlarvae $(300 \mu \mathrm{m})$ migrate to the nurseries (spring migration) on high, silty tidal flats (Armonies \& Hellwig-Armonies 1992). After the first growth season, the juvenile $M$. balthica undertake a winter migration between December and March from the nurseries to the low intertidal flats and the subtidal of the Wadden Sea and North Sea (Beukema $\&$ de Vlas 1989). However, migration patterns in the Westerschelde estuary (outside the Wadden Sea) show different migration patterns, with primary settlement on the high-tidal flats and migration to low-tidal flats during the summer (Bouma et al. 2001).

Macoma balthica migrates by byssus drifting. Byssus drifting has been described for most common bivalves of the Wadden Sea, such as the blue mussel Mytilus edulis (de Blok \& Tan-Maas 1977, Lane et al. 1982, 1985, Caceres Martinez et al. 1994) and the cockle Cerastoderma edule (de Montaudouin 1997). The byssus drifting of $M$. balthica has been described by Sörlin (1988) and Beukema \& de Vlas (1989). Due to an increase in drag force by a byssus thread, the sinking rate of juvenile molluscs decreases greatly. Sinking rates for small bivalves with a byssus thread can be up to 5 times slower than of those without, and are dependent on shell size and thread length (Sörlin 1988, Beukema \& de Vlas 1989, Beaumont \& Barnes 1992, de Montaudouin 1997). Current velocities of $0.1 \mathrm{~cm} \mathrm{~s}^{-1}$ are sufficient to enable ascent from the sediment surface (Lane et al. 1985).

For Macoma balthica, some of the factors that may promote nursery use have been identified. Beukema (1993) concluded that juvenile $M$. balthica avoid the low intertidal because of the high abundance of epibenthic predators such as shrimps and crabs, which select for small shellfish (Reise 1978, Kaiser et al. 1990). Adult $M$. balthica are predominantly eaten by birds, which can forage for longer daily periods in the high than in the low intertidal (Hulscher 1982). Growth rates have been studied at many locations, but no distinction between 0-group and older animals was made in most studies (Beukema 1993, Harvey et al. 1993, Wanink \& Zwarts 1993). Further, maximum growth rates were found in the high intertidal in some studies, while in other studies the highest growth rates were found in the low intertidal. However, whether the migration to and from the nursery itself has any negative fitness consequences has never been investigated. Therefore, the total costs and benefits of nursery use for the $M$. balthica population cannot be evaluated.

Metapopulation ecology stresses the importance of migrations between populations for the survival of the metapopulation (Hanski 1999). The theory stresses the importance of estimating the costs of migrations, as the cost of migration is equivalent to the cost of living in a metapopulation. Further, it leads to some interesting questions, such as whether subtidal Macoma balthica represent a population, because it is not clear if the species can survive without intertidal nurseries. On the other hand, the subtidal population may be important for the survival of the intertidal population in the case of extreme physical harshness, such as extremely cold winters. Metapopulation theory was largely developed in terrestrial habitats and still has to demonstrate its validity in the marine environment. This paper contributes to the latter aim, by describing a migration pattern not encountered on land.

The present paper presents the costs and benefits of nursery use by a Macoma balthica population in the Groninger Wad, eastern Dutch Wadden Sea, focussing on the population consequences of migration. We describe the migration from the low intertidal to the nursery in spring and from the nursery to the low intertidal and subtidal in the next winter for 1 year class of M. balthica. We try to quantify the migration flows of $M$. balthica as it migrates to and from the nursery. Further, we attempt to estimate the additional mortality caused by these migrations. 


\section{MATERIALS AND METHODS}

Study area. Our study was carried out in the Groninger Wad, which is part of the Lauwers basin, in the eastern Dutch Wadden Sea $\left(6^{\circ} 31^{\prime} \mathrm{E}, 53^{\circ} 27^{\prime} \mathrm{N}\right)$ (see Fig. 1). The average tidal range is $2.4 \mathrm{~m}$. The tidal flat area ranges from -1.4 to $+1.0 \mathrm{~m}$ NAP (Dutch Ordnance level, which is close to mean tidal level); saltmarshes occur at the higher levels. Mean high water (MHW) is at $+1.0 \mathrm{~m}$, mean low water (MLW) at $-1.4 \mathrm{~m}$ NAP. On the salt marsh side, brushwood groynes of former land reclamation works enclose the tidal flat area above $+0.3 \mathrm{~m}$ NAP. Sediments range from fine sand to fine silt. The studied area $\left(7.9 \mathrm{~km}^{2}\right)$ is enclosed by salt marsh on the south side, the shallow shipping gully to Noordpolderzijl on the eastern side, the deep $(10 \mathrm{~m})$ tidal channel Zuidoost-Lauwers on the northern side and partly by another shallow tidal channel on the western side.

Additional density data were collected in the tidal channels of the Lauwers basin and adjacent North Sea. The mouths of the main tidal channels Lauwers and Eilanderbalg are close to each other. It is impossible to deduce the origin of Macoma balthica (ZuidoostLauwers or Eilanderbalg) in the North Sea from their geographical position in the area. Therefore, Wadden Sea data for these areas were also combined.

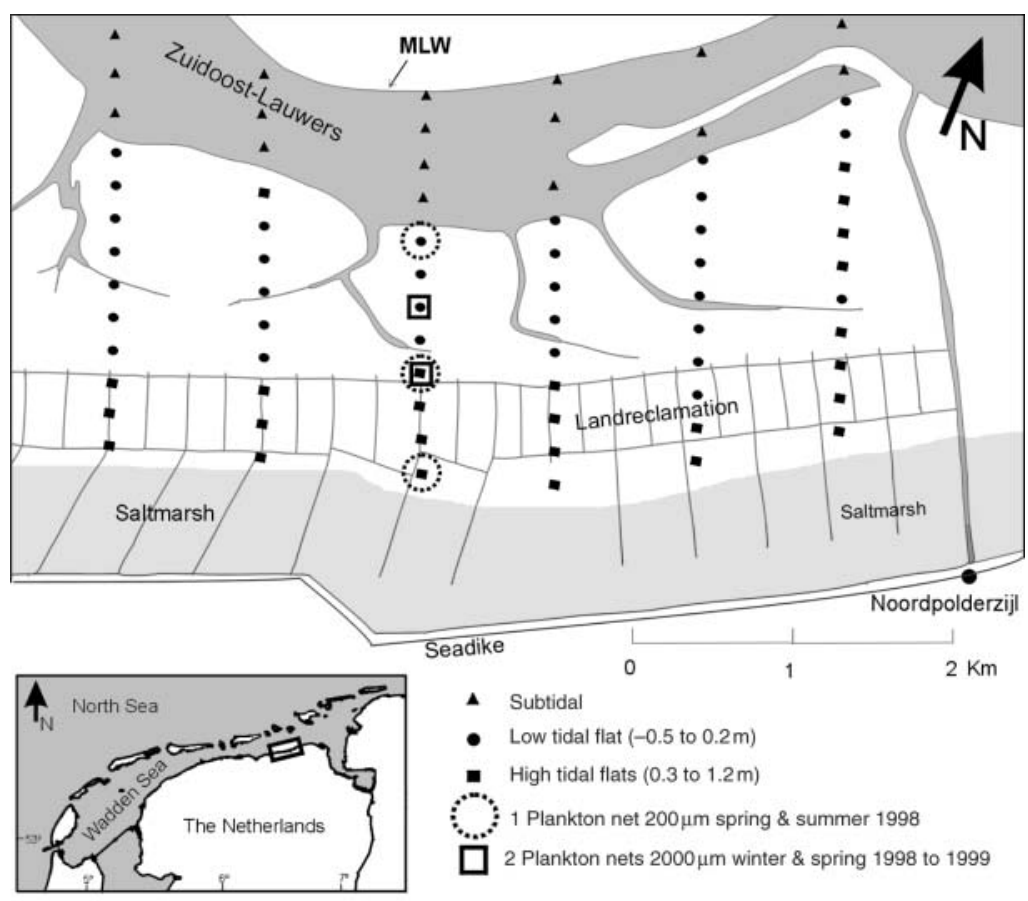

Fig. 1. Sampling stations at the Groninger Wad, eastern Dutch Wadden Sea, showing locations of plankton nets $(200 \mu \mathrm{m}, 1$ net per location) in spring and summer 1998, and coarse plankton nets $(2000 \mu \mathrm{m}, 2$ nets per location) in winter and spring (1998-1999). MLW: mean low-water level
(See Fig. 5 for the boundaries of these tidal basins, based on de Boer [1978], Ridderinkhof et al. [1990] and Louters \& Gerritsen [1994]). The North Sea area considered there is defined by the area enclosed by lines heading straight NW of the centres of the barrier islands of Schiermonnikoog and Rottumerplaat to $14 \mathrm{~km}$ offshore. The area extends more to the west than to the east because ebb currents from the Wadden Sea are directed westwards in this area (de Boer 1978). Residual currents are directed eastwards in the southern North Sea, but are of little importance to migrating $M$. balthica as these bivalves are probably mainly present in the water column during ebb tides. The tidal basin consists of $139 \mathrm{~km}^{2}$ of tidal flats and $48 \mathrm{~km}^{2}$ of tidal channels. Tidal channels reach a maximum depth of $18 \mathrm{~m}$ below NAP. The studied part of the North Sea has an area of $265 \mathrm{~km}^{2}$ and a maximum depth of $20 \mathrm{~m}$.

Our study required that there was no net migration to or from other tidal flat areas that were not sampled, because this could lead to either an over- or underestimate of mortality. We assumed that the net displacement of Macoma balthica across the western and eastern boundaries of this area was negligible since the currents over the tidal flats are mainly directed north-south and vice versa (Essink 1978) and because this assumption was a prerequisite for making estimates at all. We also assumed that net exchange across the major tidal channel, ZuidoostLauwers, was negligible since this channel has strong tidal currents running west-east and vice versa.

Set-up. The density of Macoma balthica of the 1998 year class was monitored at the tidal flat area studied from May 1998 to August 2000. During this period, the density of $M$. balthica was estimated 21 times at 57 intertidal stations. Mortality was estimated from the rate of decrease in population size. By comparing mortality, or rather disappearance, before, during and after the migration, the amount of additional 'mortality' caused by the migration can be estimated. Subtidal densities of 1998 and 1999 year class $M$. balthica were examined in October 1999.

Intertidal benthic sampling. The size of the Macoma balthica-spat population on the tidal flat was estimated from 7 May 1998 to 16 August 2000 by repeated sampling of 57 stations (Fig. 1). Of these 57 stations, 25 were located in the high intertidal (between 0.3 and $1.2 \mathrm{~m}$ above NAP) and 32 were located in the low intertidal (between $0.5 \mathrm{~m}$ below and 
$0.2 \mathrm{~m}$ above NAP). The height levels of stations and all areas were obtained from Rijkswaterstaat depth charts of the Wadden Sea surveyed in 1994. Although MLW was $1.4 \mathrm{~m}$ below NAP and some stations were horizontally close to MLW, the height of the lowest stations was $0.5 \mathrm{~m}$ below NAP. This is because the transition of the Zuidoost-Lauwers tidal channel to the adjacent tidal flats has a relatively steep slope (1:20).

Table 1 gives the dates on which the stations were sampled. Sampling started in early May, because at this time further settlement of postlarvae was assumed to be rare and therefore the population had become 'closed', a prerequisite for our calculations. With decreasing densities and increasing size of Macoma balthica, the sample size and sieve mesh size were increased from $13 \mathrm{~cm}^{2}$ and $125 \mu \mathrm{m}$ on 7 May 1998 to $415 \mathrm{~cm}^{2}$ and $1000 \mu \mathrm{m}$ at the end of the study (Table 1). On some of the sampling dates, 1 or 2 of the lowest stations could not be sampled due to high water levels at low tide. We did not correct for these missing values.

The samples were stored at $-25^{\circ} \mathrm{C}$ until sorting. Samples were sieved through 1000, 500, 300 and $125 \mu \mathrm{m}$ mesh (only those mesh sizes equal or larger than the mesh size used in the field on a date were used). The fractions were sorted at 6 to $25 \times$ magnification under a binocular dissecting microscope. The shellfish were classified in year classes by counting year rings on the shells and the number of Macoma

Table 1. Macoma balthica. Intertidal benthic and plankton sampling: dates, number of stations, area sampled, mesh sizes of sieves and plankton nets and the water temperature for the sampling dates in winter

\begin{tabular}{|lccccc|}
\hline Date & $\begin{array}{c}\text { No. of } \\
\text { stations }\end{array}$ & $\begin{array}{c}\text { Area } \\
\text { sampled } \\
\left(\mathrm{cm}^{2}\right)\end{array}$ & $\begin{array}{c}\text { Mesh size } \\
\text { smallest sieve } \\
(\mu \mathrm{m})\end{array}$ & $\begin{array}{c}\text { Water } \\
\text { temp. } \\
\left({ }^{\circ} \mathrm{C}\right)\end{array}$ & $\begin{array}{c}\text { Mesh size } \\
\text { plankton nets } \\
(\mu \mathrm{m})\end{array}$ \\
\hline 7 May 98 & 55 & 13 & 125 & - & 200 \\
19 May 98 & 57 & 13 & 125 & - & 200 \\
3 Jun 98 & 57 & 13 & 125 & - & 200 \\
18 Jun 98 & 56 & 22 & 300 & - & 200 \\
7 Jul 98 & 56 & 22 & 300 & - & 200 \\
21 Jul 98 & 57 & 22 & 300 & - & 200 \\
4 Aug 98 & 56 & 22 & 300 & - & 200 \\
19 Aug 98 & 56 & 22 & 300 & - & 200 \\
14 Oct 98 & 56 & 43 & 300 & - & 200 \\
2 Dec 98 & 57 & 83 & 500 & -1.0 & 2000 \\
15 Dec 98 & 56 & 83 & 500 & 8.0 & 2000 \\
13 Jan 99 & 56 & 83 & 500 & 1.5 & 2000 \\
28 Jan 99 & 56 & 83 & 500 & 4.0 & 2000 \\
10 Feb 99 & 56 & 83 & 500 & -1.5 & 2000 \\
25 Feb 99 & 56 & 83 & 500 & 5.0 & 2000 \\
11 Mar 99 & 57 & 83 & 500 & 3.5 & 2000 \\
30 Mar 99 & 56 & 83 & 500 & 12.0 & 2000 \\
11 May 99 & 56 & 83 & 500 & 17.0 & 2000 \\
6 Oct 99 & 56 & 249 & 1000 & 12.5 & 2000 \\
10 Apr 00 & 57 & 415 & 1000 & - & No fishing \\
16 Aug 00 & 57 & 83 & 1000 & - & No fishing \\
& & & & & \\
\hline
\end{tabular}

balthica in the 1998 year class per sample was counted.

Subtidal benthic sampling. Since Macoma balthica can also migrate to and from the subtidal, subtidal densities of spat and newly migrated adults were examined. On 5 October 1999, M. balthica were sampled in the subtidal tidal channels, just north of the studied area (Fig. 1). At 17 stations, three or four $0.2 \mathrm{~m}^{2}$ van Veengrabs per station were taken, sieved over $2 \mathrm{~mm}$, and pooled. Samples were sorted in the laboratory. The depths of these stations range from 1.5 to $10 \mathrm{~m}$ below NAP ( $=0.1$ to $8.6 \mathrm{~m}$ below MLW). Samples were stored at $-20^{\circ} \mathrm{C}$ until sorting. For each pooled sample, the numbers of 1998 and 1999 year class M. balthica were counted. In the same week, densities of the 1998 and 1999 year classes in the intertidal were estimated as described in the preceding subsection (6 October 1999: see Table 1).

Pelagic sampling. The timing of migration by Macoma balthica spat was estimated from samples obtained with plankton nets in the intertidal during high tide. The net opening had a diameter of $19 \mathrm{~cm}$ and the net could rotate freely on a pole (see Fig. 1E in Armonies [1994]). The bottom side of the opening of the net was placed $5 \mathrm{~cm}$ above the sediment surface. On every sampling date, the plankton nets were placed on the tidal flats for $24 \mathrm{~h}$, starting at low water. Nets fished passively on the current during the immersion periods (approximately $2 \times 4 \mathrm{~h}$ ). In spring, a mesh size of 200 $\mu \mathrm{m}$ was used, in winter a mesh size of $2000 \mu \mathrm{m}$ (Table 1). From May to October 1998, single nets were used at 3 locations $(-0.3,0.0$ and $0.8 \mathrm{~m}$ above NAP) (Fig. 1). From October 1998 to October 1999, 2 nets were used at 2 locations (both at $0.0 \mathrm{~m}$ NAP). The number of $M$. balthica spat per net was counted in the laboratory on the same day.

Analysis. The period from May 1998 to October 1999 was divided into 4 periods: spring migration period, first summer period, winter migration period, and second summer onwards (Table 2), based on the number of migrating Macoma balthica caught in the plankton nets and the changes in distribution on the tidal flats. A period of migration was defined as a period with both numerous migrating $M$. balthica and a change in distribution on the tidal flats. We could not distinguish between active migration and pas- 
Table 2. Macoma balthica. Disappearance rates of 1998 year class during 4 periods in their first $2.5 \mathrm{yr}$

\begin{tabular}{|lccc|}
\hline Period & $\begin{array}{c}\text { Approximate } \\
\text { start date }\end{array}$ & $\begin{array}{c}\text { Approximate } \\
\text { end date }\end{array}$ & $\begin{array}{c}\text { Disappearance } \\
\text { rate }\left(\mathrm{d}^{-1}\right)\end{array}$ \\
\hline Spring migration & 7 May 1998 & 7 Jul 1998 & 0.0125 \\
First summer & 7 Jul 1998 & 2 Dec 1998 & 0.0084 \\
Winter migration & 2 Dec 1998 & 25 Feb 1999 & 0.0107 \\
1+ group ${ }^{\mathrm{a}}$ & 25 Feb 1999 & 15 Aug 2000 & 0.0020 \\
Average & May 1998 & 15 Aug 2000 & 0.0052 \\
a Second summer onwards & & \\
\hline
\end{tabular}

by subtracting the average disappearance before and after migration from the disappearance during migration.

Order-of-magnitude calculations. We made an order-of-magnitude calculation of the population size of Macoma balthica during the migration period (Table 3) based on: initial population size - final population size $=$ normal mortality + additional mortality \pm migration. As we assumed a closed population, bivalves could only migrate within the study area. The final and initial population sizes were calcu-

sive dislocation (due to strong currents) with our methods. For each of these periods, the rate of disappearance could be estimated, assuming an exponential population decrease, according to the formula:

$$
\mathrm{N}_{t}=\mathrm{N}_{0} \mathrm{e}^{-Z t}
$$

where $Z$ is the instantaneous disappearance rate, $t$ is time, $\mathrm{N}_{0}$ the original population size, and $\mathrm{N}_{t}$ population size at time $t$. Disappearance could be estimated by rewriting the formula as $-Z t=\ln \left(\mathrm{N}_{t} / \mathrm{N}_{0}\right)$, and doing a regression of $\ln \left(\mathrm{N}_{t} / \mathrm{N}_{0}\right)$ on $t$. The differences in disappearance rate between these periods were tested by comparing the slopes ( $Z$ values) of the regressions.

In periods without migration, all bivalves that disappear will have died; thus, disappearance equals mortality. In periods with migration, disappearance is equal to mortality plus emigration or minus immigration. In this study, 'disappearance' indicates that bivalves died or otherwise disappeared. 'Mortality' is used only in cases where it can be safely assumed that the shellfish actually died. The additional mortality and disappearance caused by migration was estimated lated by multiplying density by the total tidal-flat area. Normal mortality is the mortality that would have occurred without migration. For the spring migration, we assumed that this was equal to the mortality of the following summer. Additional mortality is the difference between the disappearance measured during migration and the assumed normal mortality. Both disappearance rates (normal and additional) were calculated for the whole population. The difference between the calculated number after normal and additional mortality at a location (based on the mortality of the whole population) and the actual number found must be migration (within the study area). Altogether $95 \%$ confidence intervals of population sizes were calculated from the low and upper confidence intervals for the density estimates.

As our sampling comprised only 1 year class during 2 years and only a small tidal flat and channel area close to the mainland, additional density data of Macoma balthica from the subtidal and intertidal of the Lauwers tidal basin and the adjacent North Sea were obtained from earlier investigations.

Table 3. Macoma balthica. Population (pop.) size of 1998 year class (109 individuals) at the Groninger Wad. Bold-face values were actually measured or taken from calculations in other tables, other values were calculated from these bold-face values (see 'Results'). Net number of migrants is the difference between the calculated 'after additional migration disappearance' and the observed 'final population size' at a location

\begin{tabular}{|c|c|c|c|c|c|c|c|}
\hline Location & Station & $\begin{array}{l}\text { Area } \\
\left(\mathrm{km}^{2}\right)\end{array}$ & $\begin{array}{l}\text { Initial } \\
\text { pop } \\
\text { size }\end{array}$ & $\begin{array}{l}\text { Pop. size } \\
\text { after normal } \\
\text { disappearance }\end{array}$ & $\begin{array}{l}\text { Pop. size after } \\
\text { additional migration } \\
\text { disappearance }\end{array}$ & $\begin{array}{l}\text { Net no. of } \\
\text { immigrants }\end{array}$ & $\begin{array}{l}\text { Final } \\
\text { pop. } \\
\text { size }\end{array}$ \\
\hline \multicolumn{8}{|c|}{ Spring migration: 7 May to 7 Jul 1998} \\
\hline Total & 57 & 7.9 & 125 & 75 & 58 & & 58 \\
\hline High intertidal & 26 & 3.6 & 29 & 17 & 13 & 15 & 29 \\
\hline Low intertidal & 31 & 4.3 & 95 & 57 & 44 & -15 & 29 \\
\hline \multicolumn{8}{|c|}{ Winter migration: 2 Dec 1998 to 25 Feb 1999} \\
\hline Total & 57 & 7.9 & 14.0 & 8.9 & 5.6 & & 5.6 \\
\hline High intertidal & 25 & 3.6 & 7.1 & 4.6 & 2.9 & -0.8 & 2.1 \\
\hline Low intertidal & 32 & 4.3 & 6.9 & 4.4 & 2.8 & 0.8 & 3.5 \\
\hline Subtidal & 19 & 2.4 & $0.0^{\mathrm{a}}$ & 0.0 & 0.0 & 0.0 & $0.0^{b}$ \\
\hline
\end{tabular}




\section{RESULTS}

\section{Intertidal density}

Fig. 2 shows the time course in densities of Macoma balthica (1998 year class) on high- and low-tidal flats. Initial settlement occurred mainly in the low intertidal, on the sandy flats close to the main tidal channel. This is reflected by much higher densities on 7 May 1998 in the low intertidal $\left(22098 \mathrm{~m}^{-2}\right)$ than in the high intertidal $\left(8244 \mathrm{~m}^{-2}\right)$. M. balthica undertook a spring migration in May and June 1998. At this time densities increased in the high intertidal and decreased greatly in the low intertidal. The density of spat in the high intertidal was significantly higher on 3 June than on 7 May (ANOVA, $p=0.05$ ). Settlement after 7 May 1998 can largely be excluded, since after this date few newlysettled $M$. balthica $<300 \mu \mathrm{m}$ were found in all samples. The density of $M$. balthica $<300 \mu \mathrm{m}$ was $433 \mathrm{~m}^{-2}$ on 7 May, $76 \mathrm{~m}^{-2}$ on 19 May and $13 \mathrm{~m}^{-2}$ on 3 June. After 3 June no M. balthica $<300 \mu \mathrm{m}$ were found on the tidal flats. This indicates that after the first sampling date, hardly any new settlement of $M$. balthica larvae occurred in the studied area, and implies a migration from the low to the high intertidal. During summer of 1998, densities in the high intertidal remained higher than in the low intertidal (ANOVA, $\mathrm{p}=0.000)$.

A second migration occurred in winter, between December and February. In this period Macoma balthica migrate from the high-tidal flats to the low-tidal flats. This is visible in Fig. 2 as the crossing of the lines of densities for the high- and low-intertidal stations between 15 December 1998 and 13 January 1999. Density in the low intertidal did not increase or decrease significantly between these dates (ANOVA, $\mathrm{p}=0.45$ ), but density in the high intertidal did decrease significantly (ANOVA, $p=0.05$ ). After the migration (from February 1999 onwards), densities in the low intertidal stayed higher than in the high intertidal (ANOVA, p =0.003). A 2-factor ANOVA on the log-transformed densities for all sample dates, with date and tidal level as factors, shows that the interaction between these 2 factors was significant (2-factor ANOVA, date $\times$ tidal level, $\mathrm{p}=0.000)$; thus the spatial distribution changed significantly over time.

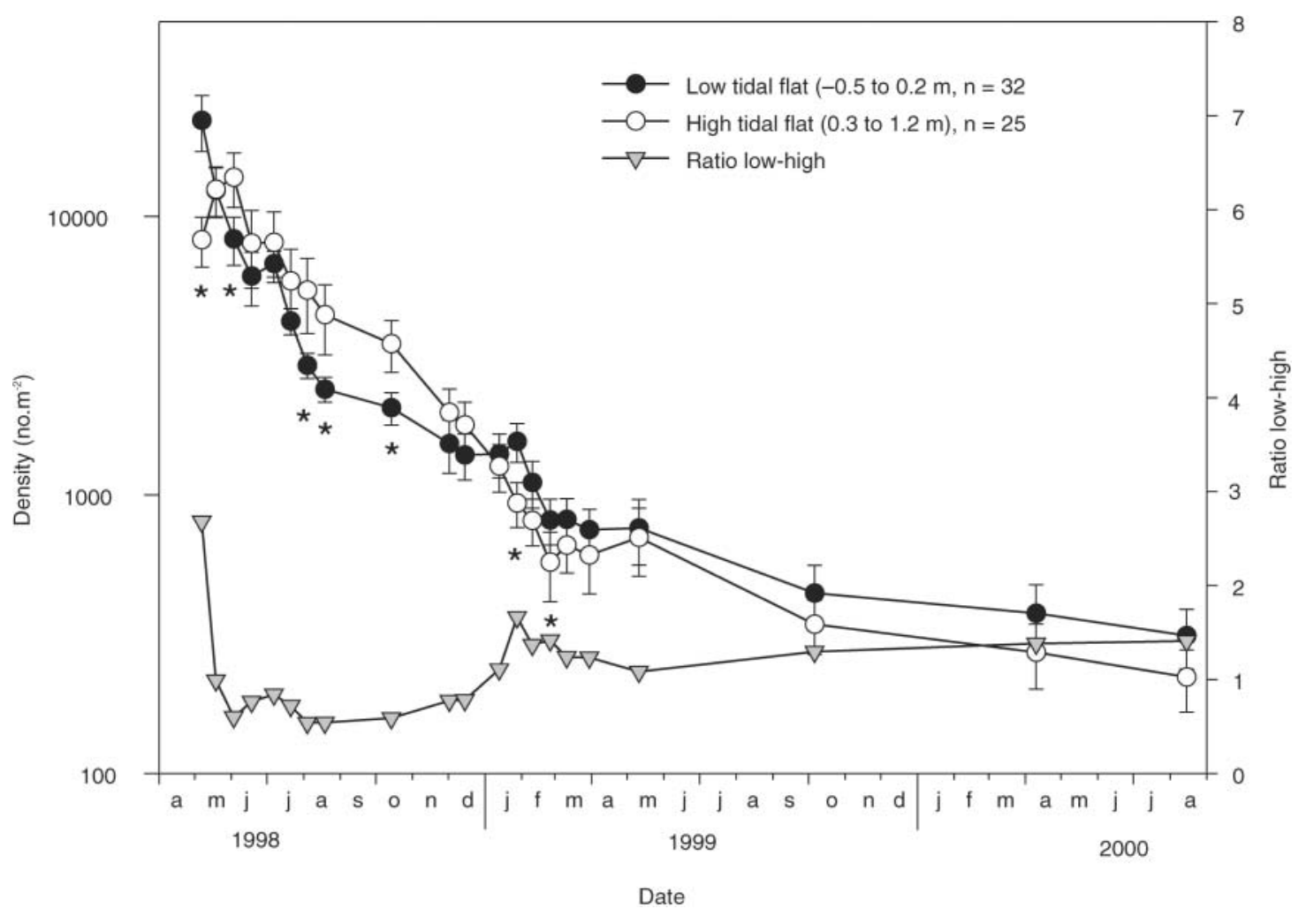

Fig. 2. Macoma balthica. Density of spat (1998 year class) $\pm 95 \%$ confidence limits in high- and low-tidal flats of the Groninger Wad from May 1998 to August 2000. Fast changes in ratio of the densities on the low and the high-tidal flats point to migration. An asterisk (*) indicates that the density differed significantly between high- and low-tidal flats in that month (Student's $t$-test on log-transformed data, $\mathrm{p}<0.05)$ 


\section{Subtidal density}

Densities of Macoma balthica in the subtidal channels for both the 1998 and the 1999 year class in October 1999 were much lower than in the intertidal. The 1999 spat had a density of $0.2 \mathrm{~m}^{-2}$ in the subtidal, while the average density in the intertidal at this time was $980 \mathrm{~m}^{-2}$. The 1998 group (1.5 yr old) had an average density of $15 \mathrm{~m}^{-2}$ in the subtidal and $400 \mathrm{~m}^{-2}$ in the intertidal at this time. The density of 1998 M. balthica in the shallow North Sea off the Lauwers (see Fig. 5) in March 1999 was $30 \pm 74$ (SD) $\mathrm{m}^{-2}$ (M. F. Leopold pers. comm.).

\section{Plankton catches, determination of migration periods and disappearance per period}

The numbers of Macoma balthica spat caught in spring and summer 1998 in the $200 \mu \mathrm{m}$ plankton nets (Fig. 3) were very low compared to the benthic densities at that time. On 4 June, the highest numbers were found in the nets (13 per net). The number of migrating M. balthica in winter reached the highest value of 1055 per net on 10 February 1999. Only 1 individual of another bivalve species, a 1 yr old Scrobicularia plana, was caught. The numbers of $M$. balthica caught in the plankton nets in winter were significantly negatively correlated with the water temperature $\left(\mathrm{R}^{2}=0.48, \mathrm{p}=0.04\right.$, Fig. 4), indicating that $M$. balthica migrates in winter. However, during winter, temperatures vary widely, with temperatures of -1 and $+8^{\circ} \mathrm{C}$ recorded in December (Table 1). Thus, the bivalves responded to water temperature.

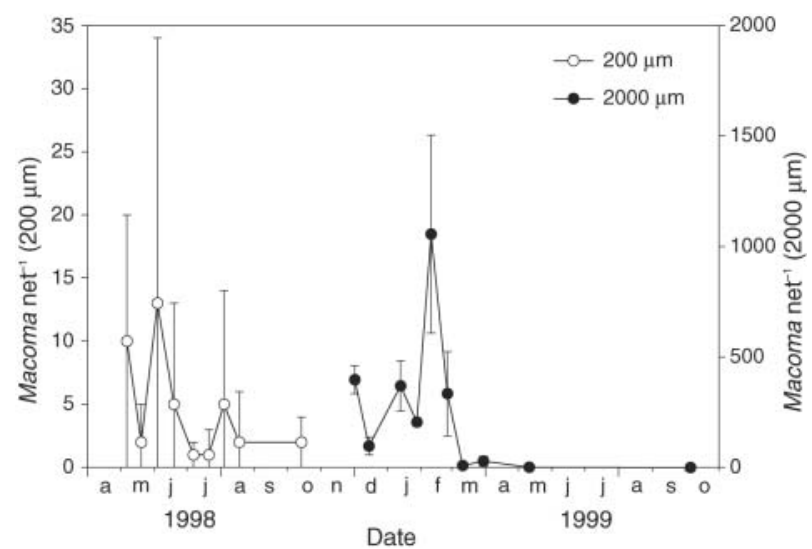

Fig. 3. Macoma balthica. Number of spat (1998 year class) $\pm \mathrm{SD}$, caught in an intertidal plankton net over $24 \mathrm{~h}$ at the Groninger Wad with a mesh width of $200 \mu \mathrm{m}$ (spring and summer 1998) or $2000 \mu \mathrm{m}$ (winter 1998-1999)
The times of the start and end of the migrations were estimated from the changes in distribution pattern (Fig. 2) and the time course of the plankton catches (Fig. 3). Fig. 2 shows the ratio of densities on the low and the high tidal flats. A fast-changing ratio in May and June 1998 and in January and February 1999 suggests a fast-changing distribution pattern in these months. These periods also showed the highest planktonic catches, but these catches suggest a longer migration period (Fig. 3). Table 2 gives the approximate dates of the start and end of the migration and the intervening periods. For each period, the disappearance rate (including immigration and emigration) of the whole Macoma balthica population (1998 year class) was estimated from the decrease in densities over the entire (low + high) tidal flat area. It is likely that mortality rates between high and low tidal flats differ. Nevertheless, disappearance rates were calculated for the whole tidal flat area with no distinction between high and low tidal flats, because migrations make it impossible to calculate disappearance rates otherwise.

The disappearance rate was significantly higher during the spring migration $\left(0.0125 \mathrm{~d}^{-1}\right)$ than during the subsequent first summer period $\left(0.0084 \mathrm{~d}^{-1}\right)$. Disappearance during the winter migration was higher than during the first and second summer periods ( 0.0107 vs 0.0084 and $0.0020 \mathrm{~d}^{-1}$, respectively). All disappearance rates were significantly different from each other.

We found a few Macoma balthica in the plankton nets after the spring migration (7 July 1998). It is not clear whether this was active migration or passive dislocation.

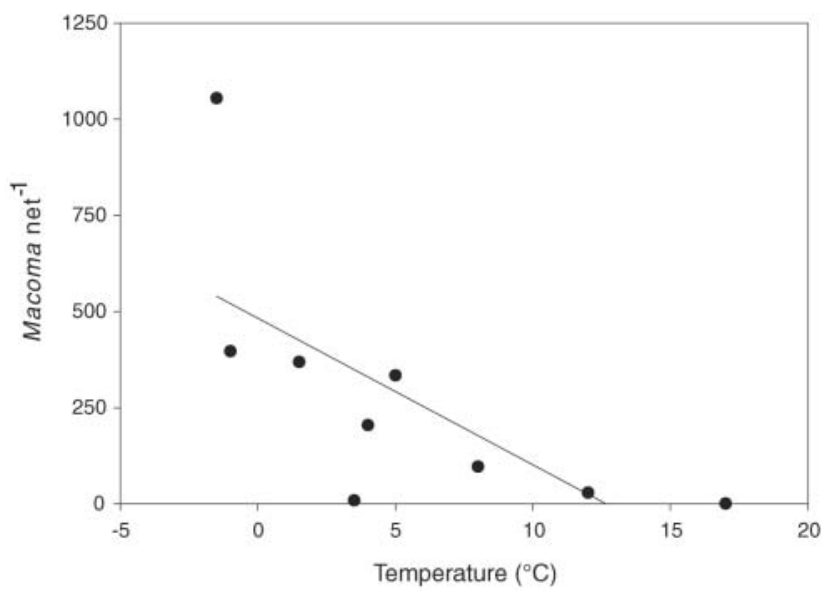

Fig. 4. Macoma balthica. Number of 1998 year class caught in a plankton net over $24 \mathrm{~h}$ at the Groninger Wad at various water temperatures from December 1998 to May 1999. $R^{2}=0.48$, $\mathrm{p}=0.04$ 


\section{Order-of-magnitude calculations}

\author{
Spring migration
}

In the Groninger Wad, densities of juvenile Macoma balthica in summer, after the spring migration, were higher in the high intertidal than in the low intertidal, and were almost zero in the subtidal of the tidal channels. Because the area of low intertidal in the study area was larger than the area of high intertidal, the total number of juvenile $M$. balthica in the 2 areas was approximately equal (Table 3: $29 \times 10^{9}$ ). The distribution and migration of juvenile $M$. balthica in this study resembles the patterns described for the German Wadden Sea by Günther (1991), Armonies \& Hellwig-Armonies (1992) and Armonies (1996), and in the western Dutch Wadden Sea by Beukema (1993).

During the spring migration, the actual disappearance rate measured during migration was $0.0125 \mathrm{~d}^{-1}$, while the normal disappearance rate was $0.0084 \mathrm{~d}^{-1}$ (Table 2). Hence, the additional disappearance rate was $0.0041 \mathrm{~d}^{-1}$. As the duration of the spring migration was $61 \mathrm{~d}, 25 \%$ of the initial intertidal population disappeared during migration (either due to mortality during the migration period or emigration to the subtidal). During this process, the normal disappearance (of $0.0084 \mathrm{~d}^{-1}$ ) of buried Macoma balthica also continued. In Table 3, the numbers of migrating and disappearing M. balthica during the spring migration were calculated from the observed density changes. The number of normal disappearances was calculated from the normal disappearance rate and the initial population size for the period of migration (61 d). The number of additional migration disappearances was calculated from the number of $M$. balthic after having subtracted normal disappearances and the additional disappearance rate for the period of migration (61 d). The difference between the number of 'additional migration disappearances' and the 'final population size' is the number that migrated.

Table 3 gives the absolute numbers of Macoma balthica in the low- and high-tidal flats before and after spring migration. Most M. balthica spat settled initially in the low intertidal. Subsequently, about $12 \%$ of the initial numbers migrated from the low-tidal flats to the high-tidal flat nurseries between May and July, while $23 \%$ of the population stayed in the low intertidal constitute $50 \%$ of the final numbers in the intertidal, so half of all surviving bivalves continued to live in the low intertidal constitute $50 \%$ of the final numbers in the interdidal, so half of all surviving bivalves continued to live in the low interdial. The rest of the population disappeared in this period. The numbers staying in the low intertidal. The numbers of $M$. balthica in the high intertidal before and after the migration were equal, while the number in the low intertidal decreased greatly: $53 \%$ of the initial numbers disappeared during the migration period, including the normal mortality of $40 \%$. The additional $13 \%$ $\left(17 \pm 5 \times 10^{9}\right.$ individuals $)$ mortality outnumbers the $15 \pm 6 \times 10^{9}$ that migrated from the low- to the hightidal flats. Since the bivalves probably did not settle in the subtidal in spring, this disappearance is presumably due to additional mortality during migration.

\section{Winter migration}

The order-of-magnitude calculations in Table 3 also show the number of migrating and disappearing Macoma balthica during the winter migration. The total disappearance rate during the winter migration was $0.0107 \mathrm{~d}^{-1}$. Parallel to normal disappearance, the additional disappearance rate (due to mortality or emigration) of $0.0055 \mathrm{~d}^{-1}$ (see Table 2 , the difference in disappearance rate between the average of the first and second summer [0.0052] and during winter migration [0.0107]) over $85 \mathrm{~d}$ resulted in $36 \%$ of the initial intertidal population disappearing.

Table 3 gives the absolute numbers of Macoma balthica on the low- and high-tidal flats before and after winter migration. Most $M$. balthica spat lived in the high intertidal throughout summer. Subsequently, about $21 \%$ of the initial numbers migrated from the high-tidal flat nurseries to the low-intertidal flats between December and February. This was $13 \%$ of the initial population on the high-tidal flats. A total of $60 \%$ of the initial numbers disappeared during the migration

Table 4. Macoma balthica. Average density $( \pm \mathrm{SD})$ and population size of 1998 year class in the Lauwers tidal basin and the adjacent North Sea, sampled in 1999. Data for North Sea from M. F. Leopold (pers. comm.)

\begin{tabular}{|lclcrc|}
\hline Location & Area $\left(\mathrm{km}^{2}\right)$ & Month 1999 & Density 1998 year class $\left(\right.$ no. $\left.\mathrm{m}^{-2}\right)$ & Population $\left(\times 10^{9}\right)$ & No. of stations \\
\hline Intertidal & 139 & March & $684 \pm 478$ & 95.1 & 56 \\
Intertidal & 139 & October & $401 \pm 218$ & 55.7 & 0.7 \\
Tidal channels & 48 & October & $15 \pm 27$ & 5.8 & 19 \\
North Sea & 195 & March & $30 \pm 74$ & 62 \\
\hline
\end{tabular}


Table 5. Macoma balthica. Population size of 1998 year class $\left(10^{9}\right.$ individuals $)$ in the Lauwers tidal basin and adjacent North Sea in winter 1998-1999. The net number of migrants is the difference between the calculated number 'after additional migration disappearance' and the observed 'final population size' at a location

\begin{tabular}{|lccccrc|}
\hline Location & Area $\left(\mathrm{km}^{2}\right)$ & $\begin{array}{c}\text { Initial } \\
\text { population } \\
\text { size }\left(\times 10^{9}\right)\end{array}$ & $\begin{array}{c}\text { Pop. size } \\
\text { after normal } \\
\text { disappearance }\end{array}$ & $\begin{array}{c}\text { Pop. size after } \\
\text { additional migration } \\
\text { disappearance }\end{array}$ & $\begin{array}{c}\text { Net no. of } \\
\text { migrants }\end{array}$ & $\begin{array}{c}\text { Final } \\
\text { pop. } \\
\text { size }\end{array}$ \\
\hline High intertidal & 23 & 45 & 29 & 22 & -9.3 & 13 \\
Low intertidal & 116 & 185 & 118 & 0 & 2.7 & 94 \\
Tidal channel & 48 & 0 & 0 & 0 & 5.7 & 6 \\
North Sea & 195 & 0 & & 0 & 0.8 & 6 \\
\hline
\end{tabular}

period, including the normal mortality of $36 \%$. The additional $24 \%\left(3.4 \pm 0.6 \times 10^{9}\right.$ individuals $)$ mortality outnumbered the $0.8 \times 10^{9}$ that migrated from the highto the low-tidal flats and subtidal channel. If all the disappearing individuals from our study area alone migrate to the coastal North Sea (to a depth of $20 \mathrm{~m}$, this is an area of $195 \mathrm{~km}^{2}$ ), this would result in an average density of 11 bivalves $\mathrm{m}^{-2}$ in the North Sea outside the Lauwers tidal basin.

\section{Winter migration of 1998 year class in whole Lauwers tidal basin and adjacent North Sea}

In order to calculate the actual density of the 1998 group of Macoma balthica in the North Sea in 1999, we must consider the entire tidal basin of the Lauwers and Eilanderbalg. This basin consists of $139 \mathrm{~km}^{2}$ of tidal flats and $48 \mathrm{~km}^{2}$ of tidal channels. Density in the intertidal was about $20 \times$ the density in the North Sea and tidal channels (Table 4), indicating that almost $95 \%$ of the $M$. balthica 1998 year class was still in the intertidal in 1999 at the end of the winter migration (Table 4).

Table 5 shows an order-of-magnitude calculation of the migration of Macoma balthica in the Lauwers tidal basin during the winter migration, assuming that the subtidal and intertidal area sampled in the Groninger wad is representative of the whole Lauwers basin. In these calculations, we used North Sea and tidal channel densities from Table 4, ignoring differences in sampling month, since these densities were very low compared to intertidal densities.

Of the $9.3 \times 10^{9}\left(7.8\right.$ to $\left.10.6 \times 10^{9} 95 \% \mathrm{CL}\right)$ migrants that leave the high intertidal, $62 \%$ migrate to the North Sea and only $30 \%$ to the low intertidal. A small fraction of $7 \%$ migrates to the tidal channels. There are however still an additional $34 \times 10^{9}$ (28 to $40 \times 10^{9} 95 \%$ CL) individuals disappearing during migration. This is thus more than 9 times the number arriving in the North Sea. Therefore, taking the North Sea population into the calculations does not explain the large proportion of disappearing Macoma balthica.
Comparison of Tables 3 and 5 changes our picture of the migration flow drastically. Taking migration to the North Sea into the calculations reveals that migration from the high to the low intertidal is only of minor importance, with two-thirds of the bivalves migrating to the North Sea.

\section{Densities in the subtidal Wadden Sea and adjacent North Sea in other years}

Additional density data for Macoma balthica from the subtidal and intertidal of the Lauwers tidal basin and the adjacent North Sea from earlier studies (Fig. 5) are given in Table 6. These densities were

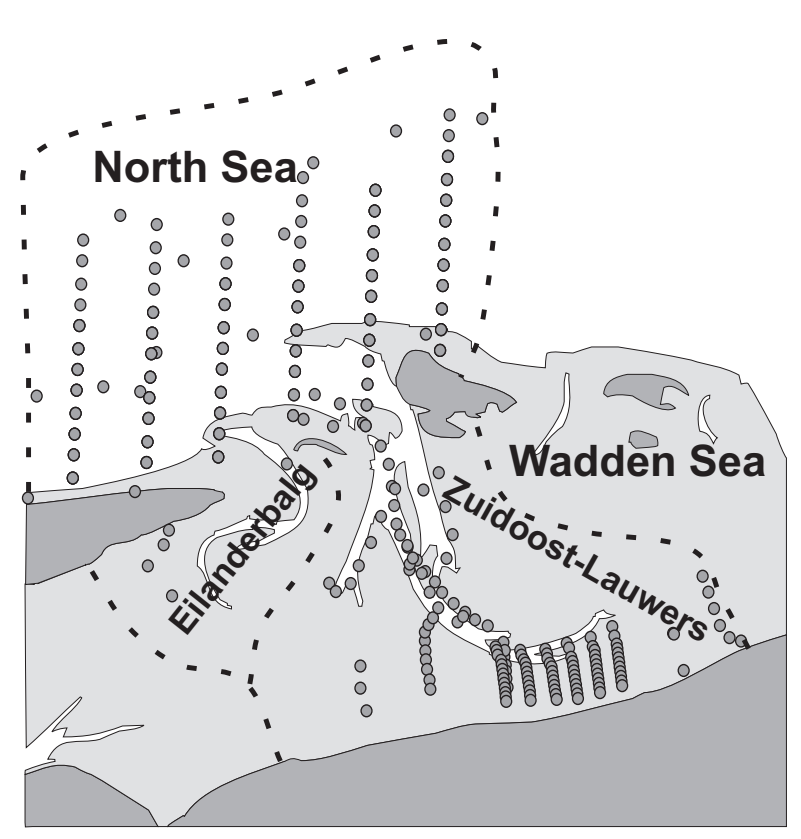

Fig. 5. Macoma balthica. Sampling stations of sources in Table 6 that provided densities from the subtidal and intertidal of the Lauwers tidal basins (Wadden Sea) and adjacent North Sea. Boundaries of the Lauwers and Eilanderbalg basin are indicated by dashed lines 


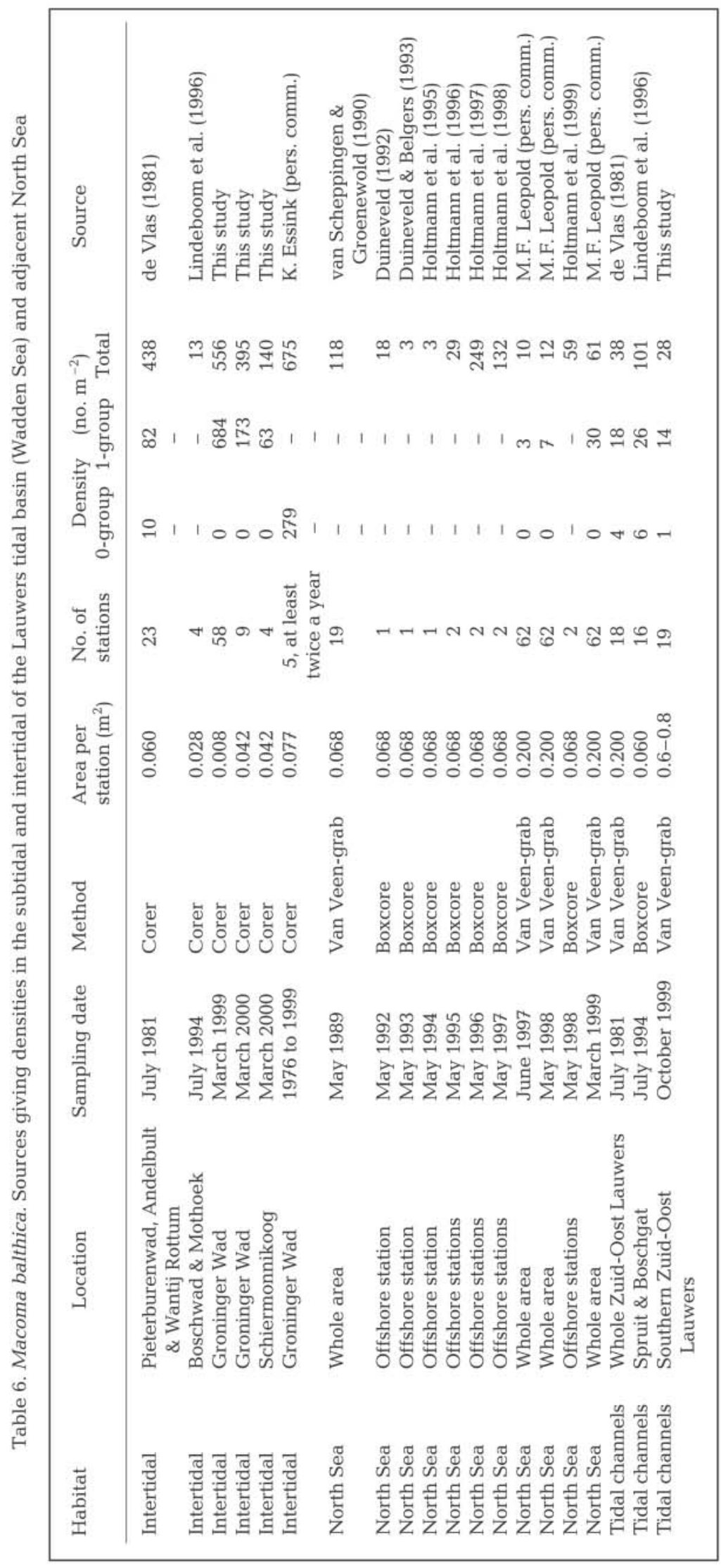

used to calculate the average density per regional compartment (North Sea, tidal channels and tidal flats). Whenever available, densities of 0-group, 1group and older individuals were calculated separately. Together with the area of each of these compartments, the average total population size of $M$. balthica per age-class was calculated from these data.

Most studies sampled the North Sea from March to May. Postlarval Macoma balthica settle in April and are small ( $<2 \mathrm{~mm}$ ) until early June, and therefore pass through the coarse sieves used in subtidal sampling. Thus, few studies sampled in the North Sea in the months that 0-group $M$. balthica were present and large enough to be retained in the sieves. This explains why in none of the studies in Table 6, 0-group $M$. balthica was found in the North Sea. For older (and thus larger) ageclasses, the sampling month was not so important, since between year class differences in density are much larger than between month differences (Beukema et al. 1996).

Table 7 gives the average densities in the different habitats. In the North Sea, older Macoma balthica were found to a depth of $20 \mathrm{~m}$. Densities of 1-group individuals were generally low (densities of 0 to $790 \mathrm{~m}^{-2}$ at individual stations) in the subtidal of both the tidal channels and the North Sea. In the intertidal, M. balthica was more numerous, up to $7300 \mathrm{~m}^{-2}$. Only $10 \%$ of the population of the Lauwers basin dwelt in the North Sea in the studied period, and thus the majority were in the intertidal (Table 7). Since both the density of $M$. balthica and the area of the tidal channels were low, the population size in the tidal channels was negligible.

When comparing densities and population size of the 1998 year class after 1 yr (Table 4) with the data for many year classes from 1976 to 2000 (Table 7), the correspondence in densities at the locations is striking: around $10 \%$ of the population dwelt in the North Sea, only $1 \%$ in the tidal channels, and the rest on tidal flats in both tables. The absolute population size deviates by $<30 \%$. Therefore, we can conclude that the dis- 
Table 7. Macoma balthica. Average density of 1-group individuals $( \pm \mathrm{SD}$ ) from the Lauwers tidal basin and the adjacent North Sea (from all sources in Table 6)

\begin{tabular}{|lrcrc|}
\hline Area & $\begin{array}{c}\text { Area } \\
\left(\mathrm{km}^{2}\right)\end{array}$ & $\begin{array}{c}\text { Density } \\
1 \text {-group }\end{array}$ & $\begin{array}{c}\text { Population } \\
\left(\times 10^{6}\right)\end{array}$ & $\begin{array}{c}\text { No. of } \\
\text { stations }\end{array}$ \\
\hline Intertidal & 139 & $511 \pm 490$ & 71029 & 88 \\
Tidal channels & 48 & $17 \pm 42$ & 833 & 49 \\
North Sea & 265 & $30 \pm 56$ & 7966 & 207 \\
\hline
\end{tabular}

tribution of 1998 year class Macoma balthica in 1999 is representative for other years.

\section{DISCUSSION}

When estimating mortality in a population, it is necessary that the population be closed. In this study, settlement was very low after the start of the observations and therefore did not interfere with the estimates of disappearance rates. However, migration into and from the research area was not examined. Since, according to detailed maps of the area, sediment and other physical and biological circumstances are quite homogeneous inside and outside the research area, and since currents over the flats are mainly northsouth and vice versa, it was assumed that there was no net lateral migration in and from the area. Immigration and emigration from and to the subtidal cannot be excluded, but is probably not a significant process (Armonies 1996).

Low water temperatures accompanied the winter migration. Sörlin (1988) had already found this in a laboratory study. It is unclear if this temperature dependency is only a trigger, or if it also has a functional component. It is known that Macoma balthica is somewhat sensitive to freezing (Ibing \& Theede 1975).

\section{Effect of sampling month and mortality values}

The effect of differences in sampling months, differences in mortality between the habitats, and the interaction between these needs some consideration. Densities in the North Sea and on the tidal flats were sampled directly after the winter migration, while densities in the tidal channels could only be sampled half a year later (Table 4). As mortalities in these different habitats are probably not equal, densities cannot be compared without reservation. Actual mortality values in the subtidal channels and North Sea were not measured and are not reported in the literature.
The ratio between individuals older than 1 yr and 1-group individuals can give an idea of the mortality at a location: a low ratio suggests a high mortality and vice versa. In October 1999, we found $9 \% \geq 2 \mathrm{yr}$ Macoma balthica in the tidal channels, and $17 \%$ in the intertidal. This suggests a higher mortality in the tidal channels. The North Sea data do not allow an estimation of mortality. The densities of some year classes at stations sampled in early spring of 3 consecutive years (1997, 1998 and 1999) seemed to increase (M. F. Leopold pers. comm.). This suggests a further migration of $M$. balthica to the North Sea at an older age. The origin and migration mechanism of these older individuals still need to be clarified. Older individuals can also migrate pelagically: in January 2001, we found five 1-group $M$. balthica together with 2241 migrating 0-group in a plankton net on the Groninger Wad tidal flats. Together, these differences in mortality and sampling month will have led to an (unquantifiable) underestimate of migration to the tidal channels and the North Sea.

\section{Explaining disappearance}

During both migration periods, many Macoma balthica disappeared from our study area. For the winter migration, part of this disappearance can be explained by migration to the North Sea. This pattern of increased mortality during spring and winter is not found for non-migrating populations of $M$. balthica (for example in the Baltic Sea [Bonsdorff et al. 1993]) or for non-migrating species like Cerastoderma edule (Jensen 1992, Guillou \& Tartu 1994). Therefore, the high disappearance rates during the migration period were probably not caused by a higher predation rate on buried $M$. balthica. The rest of the disappearing individuals were possibly victims of predators, although many other factors co-varied. Laboratory experiments showed that $M$. balthica is indeed more vulnerable to epibenthic predators such as flatfish and the crab Carcinus maenas during migration than when they remain buried (Hiddink et al. in press). It is, however, not yet clear whether this can quantitatively explain the disappearance of all migrating $M$. balthica.

Densities of the shrimp Crangon crangon, the crab Carcinus maenas, and the goby Pomatoschistus sp. on the tidal flats are generally lower during the spring and winter migration than before and after these migrations (Beukema 1991, 1992). The fact that disappearance is higher in a period when predators are scarce means that the actual impact of migration losses on the population size may be even larger than that estimated in this study. 


\section{GENERAL}

Macoma balthica spat were more abundant in highthan in low-tidal flats during their first summer. Since there is more low- than high-tidal flat, half of the spat lived in the high intertidal while the other half lived in the low intertidal. Adults lived in both the high- and low-tidal flats, but were more common in the low-tidal flats. Therefore, nursery use is not obligatory for juvenile $M$. balthica, and adults can live in the nurseries. Still, $M$. balthica do undertake migrations. As no juveniles were found in the North Sea, the Wadden Sea tidal flats must serve as an exclusive nursery for the North Sea population.

This study shows that there is a large risk associated with migration. Therefore, nursery use has to have a large advantage for the juvenile $M$. balthica. Beukema (1993) summarised the knowledge on differences in growth and survival between juvenile and adult M. balthica. Many of these differences may indeed promote nursery use. Several studies have shown that circumstances are more favourable for juveniles in the high intertidal nurseries and in the low intertidal for adults.

The advantages and disadvantages for adults and juveniles of living in the North Sea have not been investigated. It is difficult to evaluate the disadvantages for 0-group Macoma balthica in the North Sea, as these rarely occur outside the tidal flats. We assume that, for spat, environmental conditions in the North Sea are not so good, as they do not occur there. We hypothesise that this is caused by predation by flatfish, the shrimp Crangon crangon and the crab Carcinus maenas on small $M$. balthica, and that spat are thus forced to live in the high intertidal, where these predators are scarce.

The winter migration to the North Sea is especially dangerous, since the number of individuals disappearing during this migration is much higher than the number arriving in the North Sea. This implies that living in the North Sea is of great advantage to the adults. The nature of this advantage has never been investigated. Possibly, survival of adults is much higher in the North Sea, as very old adults are much more numerous there than in the intertidal. In the long run, the North Sea population might ensure survival of the metapopulation in the case of extremely cold winters.

However, most Macoma balthica either stay in the high intertidal or migrate to the low intertidal. We cannot exclude the possibility that migration to the North Sea in winter is no more than a side effect of migration from the high to the low intertidal, whereby low-intertidal arrivals have the advantages of migration (better growth rates, avoidance of predation and parasites), while the North Sea individuals have passed the best places.
Acknowledgements. Rob Dekker (NIOZ), Suzanne Holtmann (NIOZ) and Jaap de Vlas (RIKZ) kindly provided data on densities of Macoma balthica in the Wadden and North Sea. Mardik Leopold (Alterra) provided density data for the North Sea that were of great importance for our calculations. $M$. balthica densities on the Groninger Wad (provided by the RIKZ) were collected within the framework of the monitoring program of Rijkswaterstaat (MWTL), and made available by RIKZ-Haren. The anonymous referees are thanked for their valuable comments. All students and volunteers are thanked for their help during the fieldwork.

\section{LITERATURE CITED}

Armonies W (1994) Drifting meio- and macrobenthic invertebrates on tidal flats in Königshafen: a review. Helgoländer Meeresunters 48:299-320

Armonies W (1996) Changes in distribution patterns of 0-group bivalves in the Wadden Sea: byssus-drifting releases juveniles from the constraints of hydrography. J Sea Res 35:323-334

Armonies W, Hellwig-Armonies M (1992) Passive settlement of Macoma balthica spat on tidal flats of the Wadden Sea and subsequent migration of juveniles. Neth J Sea Res 29:371-378

Beaumont AR, Barnes DA (1992) Aspects of veliger larval growth and byssus drifting of the spat of Pecten maximus and Aequipecten opercularis. ICES J Mar Sci 49: $417-423$

Beukema JJ (1991) The abundance of shore crabs Carcinus maenas (L.) on a tidal flat in the Wadden Sea after cold and mild winters. J Exp Mar Biol Ecol 153:97-114

Beukema JJ (1992) Dynamics of juvenile shrimp Crangon crangon in a tidal-flat nursery of the Wadden Sea after mild and cold winters. Mar Ecol Prog Ser 83:157-165

Beukema JJ (1993) Successive changes in distribution patterns as an adaptive strategy in the bivalve Macoma balthica (L.) in the Wadden Sea. Helgoländer Meeresunters 47:287-304

Beukema JJ, de Vlas J (1989) Tidal-current transport of thread-drifting postlarval juveniles of the bivalve Macoma balthica from the Wadden Sea (Netherlands) to the North Sea. Mar Ecol Prog Ser 52:193-200

Beukema JJ, Essink K, Michaelis H (1996) The geographic scale of synchronized fluctuation patterns in zoobenthos populations as a key to underlying factors: climatic or man-induced. ICES J Mar Sci 53:964-971

Bonsdorff E, Norkko A, Boström C (1993) Recruitment and population maintenance of the bivalve Macoma balthica (L.): factors affecting settling success and early survival on shallow sandy bottoms. In: Eleftheriou A, Ansell AD, Smith CJ (eds) Biology and ecology of shallow coastal waters. Olsen \& Olsen, Fredensborg

Bonsdorff E, Norkko A, Sandberg E (1995) Structuring zoobenthos: the importance of predation, siphon cropping and physical disturbance. J Exp Mar Biol Ecol 192: 125-144

Bouma H, Duiker JMC, De Vries PP, Herman PMJ, Wolff WJ (2001) Spatial pattern of early recruitment of Macoma balthica (L.) and Cerastoderma edule (L.) in relation to sediment dynamics on a highly dynamic intertidal sandflat. J Sea Res 45:79-93

Caceres Martinez J, Robledo JAF, Figueras A (1994) Settlement and post-larvae behaviour of Mytilus galloprovincialis: field and laboratory experiments. Mar Ecol Prog Ser 112:107-117 
de Blok JW, Tan-Maas M (1977) Function of byssus threads in young post-larval Mytilus. Nature 267: 558-558

de Boer M (1978) Waterbeweging in aanlopen en buitendelta's van de zeegaten van de Waddenzee. Notitie 78H248 Rijkswaterstaat, Directie Noord-Holland, studie dienst, Hoorn, p 1-33

de Montaudouin X (1997) Potential of bivalves' secondary settlement differs with species: a comparison between cockle (Cerastoderma edule) and clam (Ruditapes philippinarum) juvenile resuspension. Mar Biol 128:639-648

de Vlas J (1981) Effectenstudie pijpleiding F3-Eemshaven: voorselectie van 3 nader te onderzoeken trace's door de Waddenzee. Report 1-38. Rijksinstituut voor Natuurbeheer, Den Burg

Duineveld GCA (1992) The macrobenthic fauna in the Dutch sector of the North Sea in 1991. NIOZ-rapport 1992-6, 1-55. Netherlands Institute for Sea Research, Den Burg

Duineveld GCA, Belgers JJM (1993) The macrobenthic fauna in the Dutch sector of the North Sea in 1992. NIOZ-rapport 1993-11, 1-55. Netherlands Institute for Sea Research, Den Burg

Essink K (1978) The effects of pollution by organic waste on macrofauna in the eastern Dutch Wadden Sea. Publication Series Netherlands Institute for Sea Research, Den Burg

Farke H, de Wilde PAWJ, Berghuis EM (1979) Distribution of juvenile and adult Arenicola marina on a tidal mud flat and the importance of nearshore areas for recruitment. Neth J Sea Res 13:354-361

Flach EC (1992) The influence of four macrozoobenthic species on the abundance of the amphipod Corophium volutator on tidal flats. Neth J Sea Res 29:379-394

Flach EC, Beukema JJ (1994) Density-governing mechanisms in populations of the lugworm Arenicola marina on tidal flats. Mar Ecol Prog Ser 115:139-149

Flach EC, de Bruin W (1994) Does the activity of cockles, Cerastoderma edule (L.) and lugworms, Arenicola marina L., make Corophium volutator Pallas more vulnerable to epibenthic predators: a case of interaction modification? J Exp Mar Biol Ecol 182:265-285

Forward RBJ, Tankersley RA (2001) Selective tidal-stream transport of marine animals. Oceanogr Mar Biol Annu Rev 39:305-353

Guillou J, Tartu C (1994) Post-larval and juvenile mortality in a population of the edible cockle Cerastoderma edule (L.) from northern Brittany. Neth J Sea Res 33:103-111

Günther CP (1991) Settlement of Macoma balthica on an intertidal sandflat in the Wadden Sea. Mar Ecol Prog Ser $76: 73-79$

Hanski (1999) Metapopulation ecology. Oxford University Press, Oxford

Harvey M, Vincent B, Gratton Y (1993) Spatial variability of length-specific production in shell, somatic tissue and sexual products of Macoma balthica in the Lower St. Lawrence Estuary: II. Large scale variability. Mar Biol 115:421-433

Hiddink JG, Kock RP, Wolff WJ (in press) Active pelagic migrations of the bivalve Macoma balthica are dangerous. Mar Biol

Holtmann SE, Duineveld GCA, Mulder M, de Wilde PAWJ (1995) The macrobenthic fauna in the Dutch sector of the North Sea in 1994 and a comparison with previous data. NIOZ-Rapport 1995-7, 1-103. Nederlands Instituut voor Onderzoek der Zee, Den Burg

Holtmann SE, Duineveld GCA, Mulder M, de Wilde PAWJ (1996) The macrobenthic fauna in the Dutch sector of the North Sea in 1995 and a comparison with previous data.
NIOZ-Rapport 1996-5, 1-103. Nederlands Instituut voor Onderzoek der Zee, Den Burg

Holtmann SE, Duineveld GCA, Mulder M, de Wilde PAWJ (1997) The macrobenthic fauna in the Dutch sector of the North Sea in 1996 and a comparison with previous data. NIOZ-Rapport 1997-8, 1-103. Nederlands Instituut voor Onderzoek der Zee, Den Burg

Holtmann SE, Duineveld GCA, Mulder M, de Wilde PAWJ (1998) The macrobenthic fauna in the Dutch sector of the North Sea in 1997 and a comparison with previous data. NIOZ-Rapport 1998-5, 1-103. Nederlands Instituut voor Onderzoek der Zee, Den Burg

Holtmann SE, Duineveld GCA, Mulder M (1999) The macrobenthic fauna in the Dutch sector of the North Sea in 1998 and a comparison with previous data. NIOZ-rapport 1999-5, 1-105. Nederlands Instituut voor Onderzoek der Zee, Den Burg

Honkoop PJC, van der Meer J (1997) Reproductive output of Macoma balthica populations in relation to wintertemperature and intertidal-height mediated changes of body mass. Mar Ecol Prog Ser 149:155-162

Hulscher JB (1982) The oystercatcher Haematopus ostralegus as a predator of the bivalve Macoma balthica in the Dutch Wadden Sea. Ardea 70:89-152

Ibing J, Theede H (1975) About freezing resistance of littoral molluscs from the German coast of the North Sea. Kieler Meeresforsch 31:44-49

Jensen KT (1992) Dynamics and growth of the cockle, Cerastoderma edule, on an intertidal mud-flat in the Danish Wadden Sea: effects of submersion time and density. Neth J Sea Res 28:335-345

Kaiser MJ, Hughes RN, Reid DG (1990) Chelal morphometry, prey-size selection and aggressive competition in green and red forms of Carcinus maenas (L.). J Exp Mar Biol Ecol 140:121-134

Klein Breteler WCM (1976) Settlement, growth and production of the shore crab Carcinus maenas on tidal flats of the Dutch Wadden Sea. Neth J Sea Res 10:354-376

Kuipers BR, Dapper R (1984) Nursery function of Wadden Sea tidal flats for the brown shrimp Crangon crangon. Mar Ecol Prog Ser 17:171-181

Kühl H (1970) Nahrungsuntersuchungen am Stint (Osmerus eperlanus L.) im Elbe-Mündungsgebiet. Arch Fisch Wiss 21:222-231

Lane DJW, Nott JA, Crisp JD (1982) Enlarged stem glands in the foot of the post-larval mussel Mytilus edulis: adaptation for bysso-pelagic migration. J Mar Biol Assoc UK 62:809-818

Lane DJW, Beaumont AR, Hunter JR (1985) Byssus drifting and the drifting threads of the young post-larval mussel Mytilus edulis. Mar Biol 84:301-308

Lindeboom HJ, Bergman MJN, and de Gee A (1996) Ecologisch minst kwetsbare locaties voor exploratieboringen in de Waddenzee en Noordzee kustzone. NIOZ-rapport 1996-4, 1-116. Nederlands Instituut voor Onderzoek der Zee, Den Burg

Louters T and Gerritsen F (1994) The riddle of the sands: a tidal system's answer to a rising sea level. RIKZ-report 94.040, 1-69. RIKZ, Den Haag

Reise K (1978) Experiments on epibenthic predation in the Wadden Sea. Helgoländer Meeresunters 31:55-101

Ridderinkhof H, Zimmerman JTF, Philippart ME (1990) Tidal exchange between the North Sea and Dutch Wadden Sea and mixing time scales of tidal basins. Neth J Sea Res 25:331-350

Sigurdsson JB, Titman CW, Davis PA (1976) The dispersal of young post-larval bivalve molluscs by byssus threads. Nature 262:386-387 
Sörlin T (1988) Floating behaviour in the tellinid bivalve Macoma balthica (L.). Oecologia 77:273-277

van Scheppingen Y, Groenewold A (1990) de ruimtelijke verspreiding van het benthos in de zuidelijke Noordzee. de Nederlandse kustzone overzicht 1988-1989. Milzon-

Editorial responsibility: Otto Kinne (Editor), Oldendorf/Luhe, Germany
Benthos Rapport 90-003, 1-27. Rijkswaterstaat, Directie Noordzee, Dienst getijdewateren, Den Haag

Wanink JH, Zwarts L (1993) Environmental effects on the growth rate of intertidal invertebrates and some implications for foraging waders. Neth J Sea Res 31: 407-418

Submitted: July 7, 2001; Accepted: October 4, 2001 Proofs received from author(s): April 19, 2002 